\title{
LIFE CYCLE ASSESSMENT OF $\mathrm{CO}_{2}$ EMISSIONS FROM INTERNAL COMBUSTION, PLUG-IN HYBRID AND BATTERY ELECTRIC VEHICLES: CALCULATING TOOLS ANALYSIS FOR THE BRAZILIAN MARKET
}

\author{
Breno H. da Silveira, a , Lílian Lefol Nani Guarieiro ${ }^{\text {. }}$ \\ a Centro Universitário Senai Cimatec, Brazil
}

\begin{abstract}
The environmental impact of a product cannot be evaluated by only the energy required to run it and for consequence the $\mathrm{CO}_{2}$ emitted from its generation. For that reason, Life Cycle Assessments (LCA) are utilized to have an extensive understanding of the impact and have the ability to compare different products. This approach must be made also for passenger vehicle with different propulsion system in the Brazilian context as the urge for electrification of its fleet becomes more intense. This context is aligned with the 17 Sustainable Development Goals from ONU on the deceleration of global warming and the use of less energy, in this case in transportation. Thereby, in this study four tools were analyzed (GREET, GHGenius, BioGrace and VSB). The tool GREET showed a more complete capability for this comparison of $\mathrm{CO}_{2}$ emissions.
\end{abstract}

Keywords: $\mathrm{CO}_{2}$ emissions; LCA; LCA tools; Powertrain electrification impact.

\section{AVALIAÇAO DE CICLO DE VIDA DA EMISSÃO DE $\mathrm{CO}_{2}$ PROVENIENTE DE VEÍCULOS MOVIDOS À MOTORES A COMBUSTÃO, HÍBRIDOS PLUG-IN E ELÉTRICOS: FERRAMENTAS DE CÁLCULO PARA O MERCADO BRASILEIRO.}

Resumo: O impacto ambiental de produto não pode ser avaliado apenas pela energia por ele utilizado duarante o seu uso e, consequentemente, pelo o $\mathrm{CO}_{2}$ emitido para a produção dessa energia. Por essa razão, uma Avaliação de Ciclo de Vida (ACV) são utilizados para entendimento mais abrangente e ser capaz de comparar diferentes produtos. Essa abordagem também precisa ser utilizada quando comparamos diferentes formas de propulsão para veículos de passageiro num momento em que a pressão pela eletrificação da frota brasileira aumenta. Tal contexto está alinhado com os 17 Objetivos para o Desenvolvimento Sustentável (ODS) da ONU para a desaceleração do aumento da temperatura global e diminuição do uso de energia, no caso dos transportes. Assim, neste estudo quatro ferramentas para esse cálculo foram analisadas (GREET, GHGenius, BioGrace e VSB). A ferramenta GREET se mostrou mais completa na comparação com as demais em relação a avaliação da emissão de $\mathrm{CO}_{2}$.

Palavras-chave: Emissões de $\mathrm{CO}_{2}$; Avaliação de Ciclo de Vida; Ferramentas de ACV; Impacto da Eletrificação do Trem de Força. 


\section{INTRODUCTION}

Brazil as member of the ONU, in 2017 signed for the 17 Sustainable Development Goals (SDGs) [1] with the commitment to promote prosperity and wellbeing for all. Building on the principle of "leaving no one behind". Climate change and its impacts on the planet is included in these 17 objectives.

According to the 5th Intergovernmental Panel on Climate Change (IPCC) [2], ONU organism dedicated to understand the risk of global warming caused by human action, it is unequivocal the temperature rise of the atmosphere and the oceans. And the human interference is the cause of it (Extremely probable $-95 \%$ to $100 \%$ of probability).

The global warming is caused by the greenhouse gas (GHG) emitted in the atmosphere. According with IPCC [2], there are $6 \mathrm{GHG}$ gases: $\mathrm{CO}_{2}$ (carbon dioxide), $\mathrm{CH}_{4}$ (Methane), $\mathrm{NO}_{2}$ (Nitrogen Dioxide), CFCs (Chlorofluorocarbons), PFCs (perfluorocarbons) e $\mathrm{SF}_{6}$ (Sulfur Hexafluoride).

The 2006 IPCC report bring us that the gases emitted by internal combustion engines for transportation are basically $\mathrm{CO}_{2}, \mathrm{NO}_{2}$ and $\mathrm{CH}_{4}-$ with $97 \%, 2-3 \%$ e $1 \%$ respectively in mass [2]. And also represents over $95 \%$ of the $\mathrm{CO}_{2}$-eq (global warming potential metric) [3]. Despite of the uncertainties on the estimates on the emissions of $\mathrm{CO}_{2}, \mathrm{NO}_{2}$ and $\mathrm{CH}_{4}$, the $\mathrm{CO}_{2}$ emissions dominates by far the pollutant emissions in the automotive business. For that reason, this paper will focus on the emissions of $\mathrm{CO}_{2}$ only.

In this context, the electrification of the fleet is being shown as an alternative to decrease its environmental impact, that historically is equipped with internal combustion engines that emits $\mathrm{CO}_{2}$ [4]. But the environmental impact of the utilization of a technology should be evaluated considering all aspects since its conception, production, utilization, maintenance and recycling. This approach is called Life Cycle Assessment (LCA).

LCA was first mentioned in the beginning of the 1960's [5] is a methodological framework and takes into consideration all steps from conception to recycling to calculate the environmental impact. Figure 1 describes in general the inputs, system boundary and the outputs. The LCA is being used in some countries to guide policy makers around the world to create and adopt new laws to realistic decrease $\mathrm{CO}_{2}$ emissions.

The complexity of a LCA will vary according to the extension of the analysis and the complexity of the product. The figure 2 shows the assessment of gasoline production until the usage as fuel of a light duty vehicle. The assessment considers impact of since extracting the petroleum, steps of transportation, refining and usage. 
Figure1. Life Cycle Stages. Source: EPA, 2006

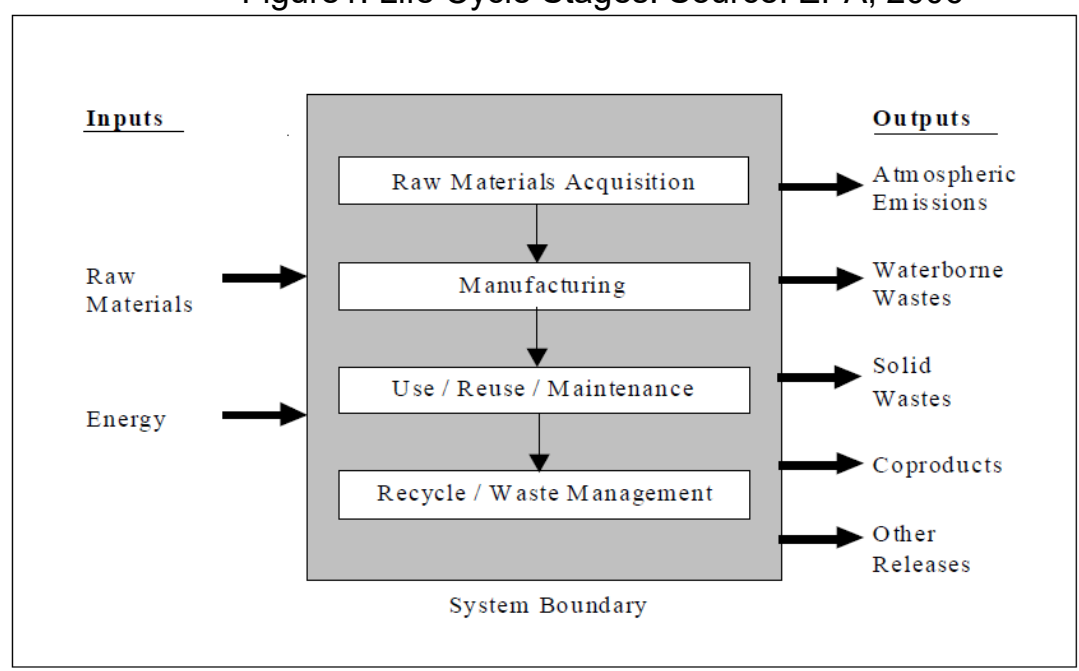

Figure 2. Gasoline life cycle schematic overview - Inputs and outputs

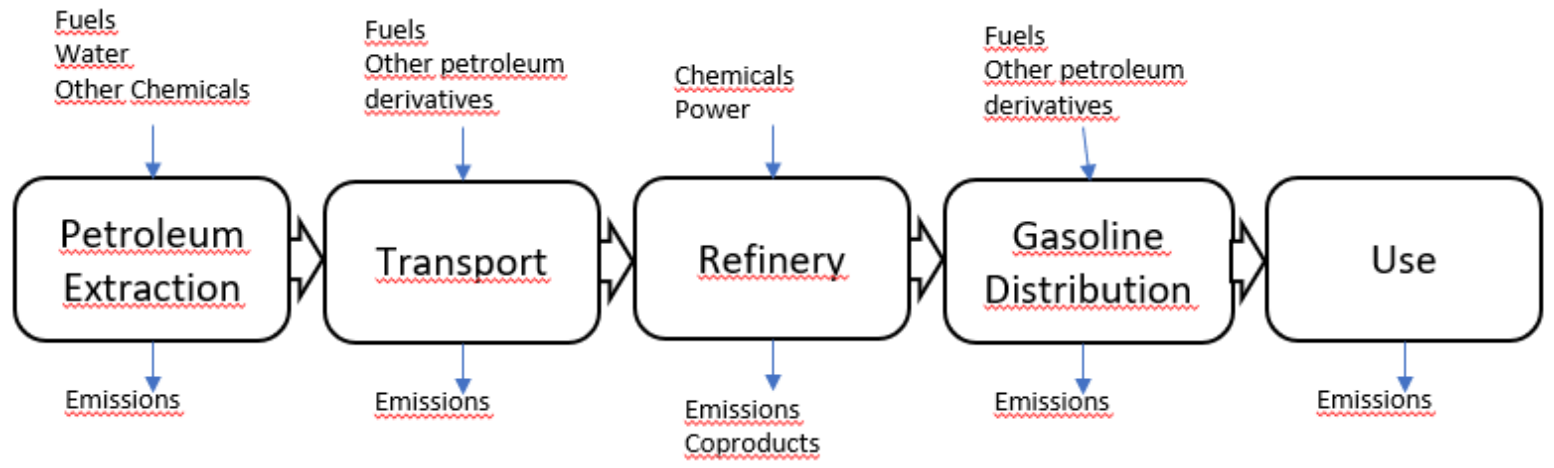

Brazil is the only country in the world that has an option of fuel $100 \%$ renewable and almost $\mathrm{CO}_{2}$ neutral. It is almost $\mathrm{CO}_{2}$ since other fuels are used on its production chain - like diesel for transportation and harvest. Figure 3 shows the assessment of ethanol production.

Figure 3. Ethanol life cycle schematic overview - Inputs and outputs

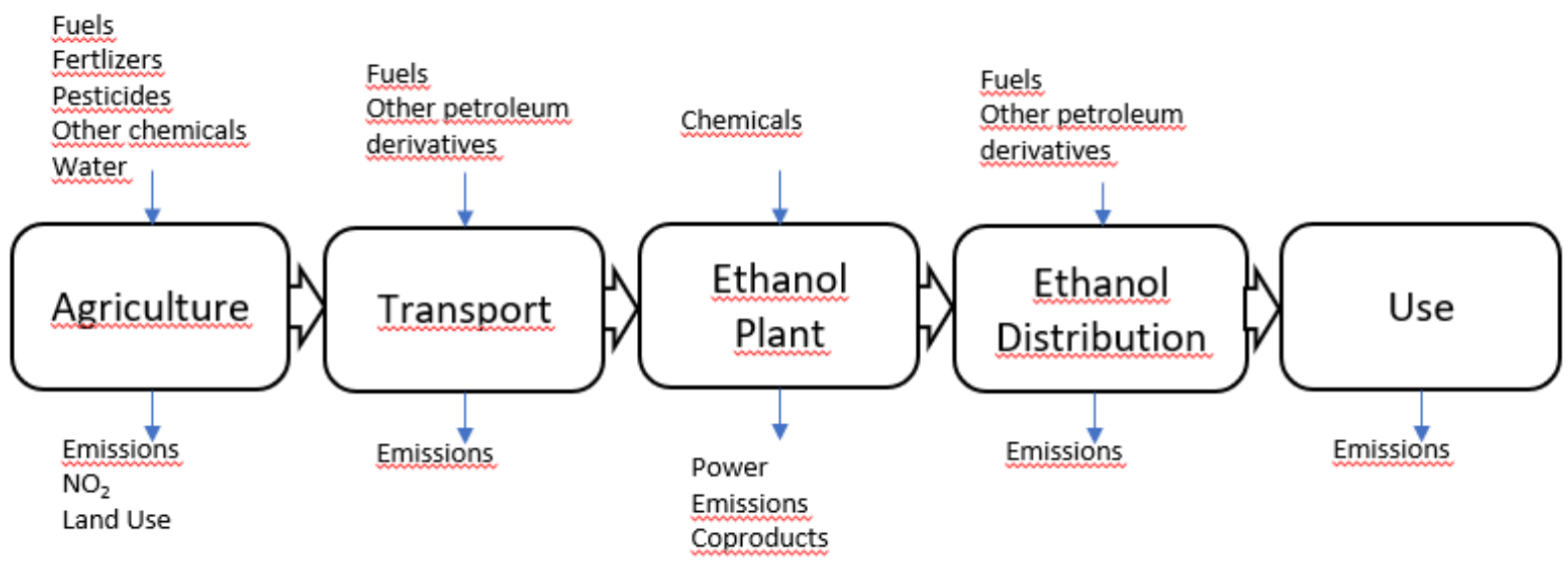

As complex it is its production and how extend is the study, LCA can be very complex, with innumerous inputs and outputs. Figure 4 shows a simplified 
assessment of a vehicle production, use and recycling.

Figure 4. Vehicle simplified life cycle schematic overview - Inputs and outputs

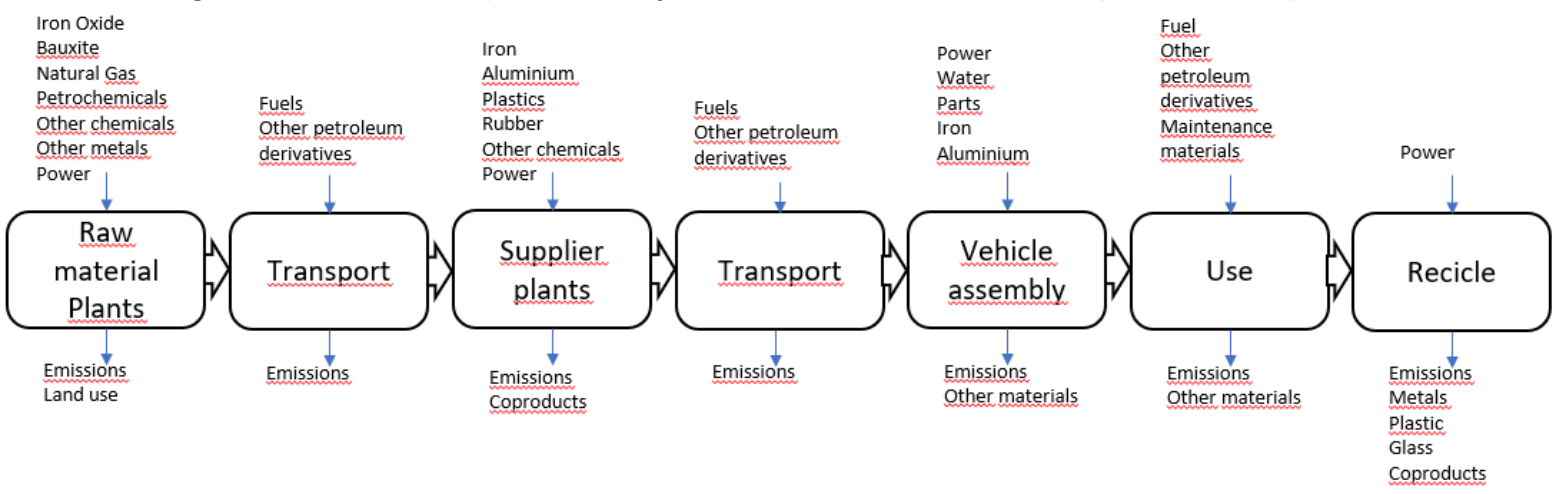

A complex analysis is required to understand all aspects and to be able to compare the $\mathrm{CO}_{2}$ emission impact of different transportation modes and powertrains. The $\mathrm{CO}_{2}$ footprint of an internal combustion engine (ICE) vehicle running with different fuels like Brazilian gasoline E27 blend (contains $27 \%$ of anhydrous ethanol in volume) [6] and hydrous ethanol (E100) [7], Plug-in hybrid vehicle (PHEV) and a battery electric vehicle (BEV) are different and to have an accurate and fair comparison, the adoption of complex math models are required.

\section{METHODOLOGY}

The research started with a review of the bibliography using key words (vehicle $\mathrm{CO}_{2}$ impact, conventional internal combustion engine versus electric vehicle $\mathrm{CO}_{2}$ impact, vehicle production energy and $\mathrm{CO}_{2}$ model) on databases: Elsevier, Scielo, Scopus, government agencies sites (EPA, ANP) and laboratories sites. The search was focused in papers produced in last 15 years, but some materials are dated from the mid-1990. The results obtained varied from calculation utilizing many methods and references [8-13] to math models like GREET, GHGenius, BioGrace and VSB. The math models found seems to be more suitable for this study and are adopted in many publications.

\section{RESULTS AND DISCUSSION}

The life cycle model identified were basically four: (i) GREET; (ii) BioGrace; (iii) GHGenius; and (iv) Virtual Sugarcane Biorefinery. They are tools developed mostly in a response to a government agency to support policy makers in their positions to improve GHGs emissions. They are the right tool to avoid biased decisions when not the whole chain is taken into consideration. The GREET model showed a more comprehensive approach and more suitable for this study.

\subsection{GREET}

The Greet (The Greenhouse gases, Regulated Emissions, and Energy use in Transport) model [8] was developed by the Argonne National Laboratories (ANL) in the mid of 1990 sponsored by U.S. Department of Energy's (DOE) Office of Energy 
Efficiency and Renewable Energy. GREET is the acronym for Greenhouse gases, Regulated Emissions and Energy use in Transportation. It is a free excel based program with more than 40.000 registers including academy members, industry and government. It has more than 80 vehicle fuel systems, more than 100 fuel production pathways and more than 65 vehicle production materials. It is being constantly updated with the latest technologies and detailed pathways. The model is free for download.

\subsection{BioGrace}

The BioGrace (Harmonised Calculations of Bioenergy Greenhouse Gas Emissions in Europe) $[9,10]$ is a greenhouse gas emission excel based calculation tool created by an European cooperation group formed by France, Austria, Spain, Greece, Germany and Sweden. Created to simplify and harmonize the calculation methodology for GHG emissions calculation and promote right comparison between biofuels that have to be made to comply with the Renewable Energy Directive (RED) and Fuel Quality Directive (FQD).

The model was made to serve two main functions: make transparent the GHG emissions calculations and allow stakeholders to make actual calculations. In its database there are 22 production biofuel production pathways listed. And it is $4 \mathrm{~d}$ version. The model is currently managed by the Institute of Energy and Environmental Research (IFEU) located in Germany. The model is free for download.

\subsection{GHGENIUS}

GHGenius is a model for LCA developed for Natural Resources Canada by $(S \& T)^{2}$ consultants [11]. It is focused in many regions of Canad but can run for Mexico, India, four regions of the European Union and North America. It can predict emissions through past to future up to 2050 from raw material acquisition to end-use.

The model is capable of calculating emissions of ICEs from a variety of vehicles since light duty passenger vehicles to heavy duty trucks including urban buses. And also, alternative powertrains like fuel cells vehicles and BEVs. With the possibility to run in the model more than 200 vehicle and fuel combinations. The model is also free for download.

\subsection{Virtual Sugarcane Biorefinery (VSB)}

The VSB was developed by the National Laboratory of Bio-Renewables located in Campinas, Brazil [12]. Former CTBE (National Lab. Of Science and Bioetanol Tecnology. It simulates the production and process of biomass targeting innovation and new technologies. Focusing on sugarcane biorefinery configurations, the tool considers sugarcane production process from agricultural production, transport, refinery process and disposal of products.

The tool takes into considerations not only the environmental impact of ethanol production but also economic (e.e. internal rate of return, net present value, and production costs) and social (e.g. number of jobs, occupational accidents, wages, 
educational level, and gender distribution) aspects [13]. This model is not free for download.

\subsection{Comparison Table}

The table 1 shows a comparison of the characteristics of the models to be considered in this study. There we can see how big is the geography amplitude, how complex is the analysis, the reason for their development, the functional unit that is based upon, the impact sectors and if it is a open source or not.

Table 1. Main characteristics of the models.

\begin{tabular}{|c|c|c|c|c|}
\hline Parameters & GREET & GHGenius & BioGrace & VSB \\
\hline Geografy & U.S. & Canada, U.S., India, Mexico & Europe & Brazil \\
\hline Considers the LCA of a Vehicle? & Yes & Yes & No & No \\
\hline Developed for Regulatory Use? & Yes & Yes & Yes & No \\
\hline Functional Unit (FU) & $\begin{array}{l}\text { Service }(\mathrm{km}, \mathrm{mile}) \\
\text { Energy }(\mathrm{Btu}, \mathrm{MJ})\end{array}$ & $\begin{array}{l}\text { Service }(\mathrm{km}) \\
\text { Energy }(\mathrm{MJ})\end{array}$ & Energy (MJ) & $\begin{array}{l}\text { Service }(\mathrm{km}) \\
\text { Energy (MJ) }\end{array}$ \\
\hline Impact Categories & $\begin{array}{c}\text { GHG, Energy, } \\
\text { Water Use, Air Pollutants }\end{array}$ & $\begin{array}{c}\text { GHG, Energy, } \\
\text { Cost Effectiveness }\end{array}$ & GHG & $\begin{array}{c}\text { GHG, Energy, } \\
\text { Ozone depletion, } \\
\text { Economic and social } \\
\text { impacts }\end{array}$ \\
\hline Open Sourced & Yes & Yes & Yes & No \\
\hline
\end{tabular}

\section{CONCLUSION}

This study can conclude that LCA of a whole vehicle is intricate and sensible to bias on understanding all aspects of $\mathrm{CO}_{2}$ emissions. Utilizing the existing models is a good starting point for a more assertive analysis. BioGrace and VSB considers only the fuel chain of production and were built to analyze transport mode that is going to use the fuels. GREET and GHGenius have the fuel chain and a variety of transport modes can be chosen to compound the analysis. GREET seems to more complete and will be chosen for this study. One fragility of all models is that none of them have the recycling, so other models shall be used to calculate the energy required to recycle the different parts of a vehicle and subsequently the $\mathrm{CO}_{2}$ emissions related to it. The most appropriated approach could be to harmonize the models bringing a better balance between their assumptions and bring a more precise results for the Brazilian market including in more detail our crops, industry, vehicle line up, local customer usage and local recycling capabilities.

\section{Acknowledgments}

The author gratefully thanks Ford Motor Company Brasil for the part scholarship in this Professional Master's Degree.

\section{REFERENCES}

1 ONU, 2015. 17 Objetivos para Transformar o Nosso Mundo (17 Objectives to Transform Our World). Nações Unidas Brasil. (accessed on January $20^{\text {th }}, 2020$ ). http://www.nacoesunidas.org/pos2015/. 
2 IPCC 2006, 2006 IPCC Guidelines for National Greenhouse Gas Inventories, Prepared by the National Greenhouse Gas Inventories Programme, Eggleston H.S., Buendia L., Miwa K., Ngara T. and Tanabe K. (eds). Published: IGES, Japan.

${ }^{3}$ Benvenutti, Lívia M. et al. The Impact of $\mathrm{CO}_{2}$ Mitigation Policies on Light Vehicle Fleet in Brazil. Energy Policy, v. 126, p. 370-379, 2019.

${ }^{4}$ Samaras, C., Meisterling, K.. Life Cycle Assessment of Greenhouse Gas Emissions from Plug-in Hybrid Vehicles: Implications for Policy. Environmental Science \& Technology, Vol. 42, Nº9, p. 3170-3176, 2008.

5 US EPA Life Cycle Assessment: Principles and Practices, 2006. $<$ http://people.cs.uchicago.edu/ ftchong/290N-W10/EPAonLCA2006.pdf $>$

${ }_{6}$ Portaria MAPA N 75 DE 05/03/2015. Ministry of Agriculture, Livestock and Supply.

7 RESOLUÇÃO ANP No 7, DE 9.2.2011 - DOU 10.2.2011. Brazilian Petroleum Agency. 2011

${ }^{8}$ ANL. GREET Model. 2019. Available at: <http://greet.es.anl.gov> . Accessed on June $4^{\text {th }}, 2020$.

${ }^{9}$ Biograce. Harmonised Calculations of Biofuel Greenhouse Gas Emissions in Europe. 2020. Available at: $<$ https://www.biograce.net/home $>$. Accessed on: July $7^{\text {th }}$, 2020

10 Biograce. Publishable $\quad$ Final 2012.

<https://www.biograce.net/img/files/BioGrace - Final_publishable_report.pdf $>$

${ }^{11}$ GHGenius. 2020. Available at: <https://www.ghgenius.ca/index.php $>$. Accessed on July $10^{\text {th }}, 2020$.

12 Pereira, L. G. et al. Comparison of biofuel life-cycle CHG emssions assessment tools: The case studies of ethanol produced from sugar cane, corn, and wheat. Renewable and Sustainable Energy Reviews 110. P. 1-12. 2019

13 Junqueira, T. L., Cavalett, O., Bonomi, A.. The Virtual Sugarcane Biorefinery - A Simulation Tool to Support Public Policies Formulation in Bioenergy. Industrial Biotechnology V. 12 NO. 1. P. 62-67. 2016. 